\title{
Organizational Culture and the "Voice" of Small Entreprises in the Electrical Engineering Service Sector in the Republic of Macedonia
}

\author{
Marjan Bojadjiev $^{1}$, Ana Tomovska Misoska ${ }^{1, *}, B^{,}$iserka Mirocevic ${ }^{1}$, Miodraga Stefanovska-Petkovska ${ }^{2}$ \\ ${ }^{1}$ School of Business Economics and Management, University American College Skopje, Republic of Macedonia \\ ${ }^{2}$ School of Political Science and Psychology, University American College Skopje, Republic of Macedonia
}

Copyright $\mathrm{C} 2018$ by authors, all rights reserved. Authors agree that this article remains permanently open access under the terms of the Creative Commons Attribution License 4.0 International License

\begin{abstract}
This paper focuses on a very important aspect of organizational functioning: organizational culture. This aspect has been linked to numerous indicators of organizational success and there are a number of efforts to measure it. However, research on organizational culture has been sparse in southeast Europe, especially for small and medium enterprises. Therefore, this paper proposes a new instrument for measuring organizational culture that was developed in southeast Europe and tests its applicability in small and medium Enterprises from the region. The study was carried out in the Republic of Macedonia using a convenience sample of employees from three companies. The results show the value of the findings for the companies as well as the applicability of the new instrument. Further validation using a representative sample is suggested.
\end{abstract}

Keywords Organizational Culture, Vox Organizations, SMEs, Republic of Macedonia

\section{Introduction}

The latest business experiences show that organizational culture is crucial for a company to perform at an extraordinary level. It is so powerful and important that when not aligned with the organizational structure, business strategy and leader's values, it represents the company's most bitter opponent on the market [1]. Organizational culture is more and more recognized as an advantage that can be applied to improve performance [2]. A number of authors have found links between the organizational culture of a company and its effectiveness $[3,4]$. Therefore, by exploring the nucleus of the values and practices that their members or groups espouse over time, many organizations strive to measure their organizational cultures. This can be achieved through the use of well-known models established by recognized authors or by adopting internally-generated methods or tools to provide tangible or understandable parameters to estimate their organizational culture and its influence on their functioning [5].

Although they represent the dominant form of business worldwide, Small and Medium Enterprises (SMEs) are researched far less regarding the phenomenon of organizational culture as a conceptual link between organizational behavior and strategic management than big enterprises are, and this is especially the case in South-East Europe (SEE). This has produced the necessity to provide a micro contribution to a very big topic in organizational behavioral sciences by conducting a research on the least explored sizes and types of business in SEE and specifically in the Republic of Macedonia.

The importance of this paper is not only that it provides data from a sparsely-studied area, but it also utilizes a fairly new instrument for measuring organizational culture, which is specifically created for measuring organizational culture in SMEs in the Republic of Macedonia.

The paper begins by exploring the theoretical foundations of organizational culture as well as the importance of organizational culture for SMEs with a special focus on the Republic of Macedonia. The paper then presents the methodological aspects of the study followed by the results of three companies from the electrical engineering service sector of Macedonia. The implications for managers as well as for future studies are discussed at the end.

\subsection{Defining and Measuring Organizational Culture}

It is agreed upon in the literature that a sole definition of organizational culture is blurry because the researchers relate organizational culture to both its source and its 
outcome [6]. The result is an emergence of a sea of definitions for organizational culture in the literature which most often define the culture in terms of causes and effects. Distinguished writers such as Schein [1] criticize that the majority of the authors on organizational culture have different definitions and approaches to determine what they mean by culture and different criteria for estimating the ways in which culture influences organizations.

In the review of cultural theories, [7] suggest that all theories on organizational culture indicate that culture is collectively learned and acted out by the organizational members. It is a company's organizational culture that can guide the personnel as to what kind of practices, values and ideas to include in their organizational life. Often cited by other theorists, Hofstede [8-10] and Schein [1], propose models that describe organizational culture through different cultural dimensions by exploring the nucleus of the values and practices that a group espouses over time. Hofstede's organizational culture model (also called Hofstede's multi-focus model) suggests that by mapping their cultures we get acquainted with the relations between people in organizations, their work and the interaction with the external environment [8]. The actual culture as is cannot predict if the organization will accomplish its mission, vision, objective and strategy, but considering that the cultural dimensions are accurately determined by translating them in terms of optimal culture it is possible to identify inconsistencies and if required, overcome the mismatches between the actual and optimal culture [10]. If practices are shaped according to the values of the organizational founders, the organizational members have to follow the practices in order to retain their organizational membership, but they do not have to accept the values of the founders [9].

The literature is a witness of numerous attempts to identify and measure the dominant type of organizational culture. The authors use affective assessment measures or self-reporting instruments in order to obtain valid data and draw conclusions based on facts (i.e. numeric indicators that would further on be used to evaluate the organizational culture and the forms in which it exists in the organizations). The literature review shows that different authors base their assessment of organizational culture on many different aspects which according to their standpoint would most closely define and signify the organizational culture.

Although the literature exhibits a large number of instruments at the scholar's disposal that can be used to obtain more precise results, a pattern of categorization can be noticed in terms of the aspects that the instruments cover. For example, the Organizational Culture Profile (OCP) [11] assesses the person-organization match and emphasizes organizational values as main component for determining the culture. Hofstede's approach, one of the most -cited concepts, examines the data from the perspective of organizational practices and their influence on the behavior of the members of the organization. The data, however, are analyzed on a group rather than on an individual level [9]. Cameron and Quin [12] use the Organizational Culture Assessment Instrument (OCAI) to identify the culture of the organization via its practices and the perceptions of its members and categorize organizational culture, according to the theoretical model of the Competing Values Framework, into one of the four culture types: clan, adhocracy, hierarchy and market. Another category of measurement is established based on the content and process of the culture and this approach is incorporated in the Global Leadership and Organizational Behavior Effectiveness (GLOBE) instrument. The purpose of the instrument is to determine the commonalities and differences in societal and organizational culture between nations through nine cultural dimensions: uncertainty avoidance, power distance, collectivism I (institutional), collectivism II (in-group), gender egalitarianism, assertiveness, future orientation, performance orientation and humane orientation [13].

\subsection{The Need for a New Instrument}

The afore-mentioned instruments are just a few of the many tools which are considered to be standardized [14]. The number of instruments for measuring organizational culture is large, so the question of whether another instrument is needed is a valid one. Nevertheless, many authors find that the existing ways of measuring organizational culture simply do not respond to the challenges and restrictions faced by the companies under focus in their studies. Therefore, they either modify the standard instruments or create their own measuring mechanisms that will suit specific projects and/or organizations. These instruments mainly come from developed countries and are mainly applied and validated in large companies. Therefore, it has been pointed out that organizational culture measurements need to be adapted to a broader cultural context $[10,15,16]$.

In addition, theories about organizational culture are almost entirely developed based on researches conducted in big organizations located in developed countries and in many of their aspects these theories are not applicable to SMEs. The core reason for this tendency according to a number of researchers $[17,18]$ lies in the fact that larger organizations are becoming even bigger and more composite, which makes them fruitful soil wherein to conduct research. The fact that the "fast-growing SMEs get a lot of attention in both national and EU policies" [19, p.82 and p.99] justifies the critique that the small and medium size enterprises have been unfairly discriminated against in terms of being observed and studied by researchers as complex cultural systems[20]. SMEs, especially those in countries with transitioning economies, such as those in South Eastern Europe, have faced a very unstable business climate over the past 20 years. This unstable climate was 
primarily created by the shift from one economic system to another and the drastic changes in their social and other legislative policies [21], as well as the global economic crises. If organizations are considered to be living systems which react to their environments and are able to adapt to varying conditions because of their more organic or flat structure, SMEs can respond to any form of environmental change with less discomfort than bigger organizations. Additionally, because of their differences in structure and the fact that they are characterized by less hierarchy, a relative lack of strict action procedures and of rigid internal and external ways of communication, SMEs are able to quickly adjust and change direction when facing economic uncertainty, but their adjustment still depends on internal characteristics such as employee beliefs and behavior, which are related to organizational culture [19]. Therefore, organizational culture measures specifically tailored to SMEs are needed.

Because of the changes of the social systems and the transition from centrally planned to market economy, the enterprises from southeast European countries are a significant challenge for the contemporary discipline of management and organizational behavior. What is interesting to note is that Macedonia as a country recently experienced a change in its political and economic system. The country was a part of Yugoslavia until the early 1990s and has been one of the less economically developed states from the time of Yugoslavia until its current state of political independence and controlled market economy [22]. Macedonia's transition to an open economy is difficult and ongoing and has had several ramifications for both enterprises and people. The country faces high unemployment especially among young people [23]. Since many of the state-owned enterprises collapsed, small and medium Enterprises have become an important part of the economy, although a number of them were created based on necessity rather than opportunity and are thus very fragile $[24,25]$. There is a general lack of research regarding culture, leadership, and organizational behavior in the country. Taking into account Hofstede's dimensions of national culture, people in Macedonia have high power distance, meaning that there is clear distinction between those that have power and those that do not. The culture is also high in uncertainty avoidance, which is understandable as the country has been in political and economic turmoil for many years. The level of individualism is low, and there is a tendency for lower masculinity, predominantly due to people valuing job security and other social benefits and at the same time emphasizing earnings [26].

One of the first studies conducted in Macedonia on organizational culture was dealing with the question whether organizational culture exists at all in Macedonian firms [27]. The organizational culture was recognized by the organization members mainly in the values set by the companies' founders. The employees show awareness of the existence of a connection between the leadership style and the organizational culture, but they do not hold the company responsible for their career advancement. A more recent research conducted on the territory of Macedonia shows that the national culture has a stronger impact on the behavior of the employees than organizational culture, and especially in the small and medium size enterprises [28]. The analysis of different models show that cultural aspects coincide to some degree and that many of the recent theories derive or evolve from the previously established ones As such, this paper utilizes VOX Organizations model [29] based on previous models and adapted to the needs of SMEs in SEE. Similar to the idea of the existence of a relationship between national and organizational culture pervading Hofstede's, Trompenaars's and Schein's theories, this model's dimensions are "developed to reflect the broader cultural environment and the needs of the organizations in Macedonia and the broader region." [29 p.7]. The instrument has been used in two previous studies measuring organizational alignment in different organizations in the Republic of Macedonia [30, 31]. Therefore an instrument that will measure organizational culture adapted to the broader culture is needed.

This paper presents another attempt to explore the organizational culture of SMEs using Vox Organizations. The paper provides the overall results of the organizational culture as well as comparisons along different demographic dimensions.

\section{Methodology}

The study was conducted in the Republic of Macedonia. The sample was drawn from three SMEs providing electrical engineering services and running their operations within and outside of Macedonia.

The instrument contains four dimensions measured on a 4 point Likert-type scales (strongly disagree; disagree; agree; and strongly agree). The four dimensions are: decision making and behavior; people versus task orientation; innovativeness and risk taking; and open versus closed system. These four dimensions are appraised by using a set of questions. To avoid a response set, some of the questions are reverse coded. The dimensions have been developed through literature review and analysis and synthesis of various other instruments and also through taking into consideration the broader cultural environment in the country and the region. The complete list of questions for the instrument can be found in Appendix 1.

The first set of questions intends to determine the level of bureaucracy in the studied Macedonian enterprises since this represents a potential danger for their development and entrepreneurial orientation as one of the key factors for elevating the company above business mediocrity. This is the Decision Making and Behavior (DMB) dimension. This dimension is emphasized in the Organizational 
Culture Inventory [32] as well as well as OCAI [12] and in the works of Hofstede et al [33]. A low score on this dimension signifies a tendency towards bureaucratic functioning and behavior strictly governed by policies and procedures. A high score means that decision making and behavior is governed by shared understanding and a shared culture of employees involved in the decision-making.

The second groups of questions are for the People-Task (PT) dimension and are related to social care or human relations within the company. This dimension is concerned with the employees taking on new challenges as part of their jobs, which has a positive impact on self-confidence, to increase their competence by investing in their education and training, to increase their job market value as members of the workforce, etc. This dimension is included in a number of other instruments [11,33]. A low score means caring about finishing tasks and a high score means caring for the well-being of employees.

The third dimension, Innovativeness and Risk Taking (IRT) is supposed to measure tendency towards risk, organizational actions as a significant indicator of resistance or acceptance of entrepreneurial actions in building the company's competitive advantage. This dimension is similar to the one used in the Organizational Culture Profile [11]. A low score means low levels of innovativeness and risk taking.

The analysis of the answers of the fourth group of questions will determine if the respondents consider their companies to belong to organizational models that do or do not depend on the surrounding environment in seeking solutions for managerial concerns, as well as the accessibility of the information to the employees and how easily or difficultly new members of the organization are accepted. This set of questions examines if the organizations are isolated from the influence of the technological advancement, societal characteristics, and the decisions of the authorities or if they are dynamically interacting with external variables like government, competition, customers and providers. This dimension is termed Open versus Closed system (OC). This is similar to a dimensions used in OCAI [12]. A low score means the organization is closed organizations and a high score means the organization is open.

To construct the instrument, a pool of questions was compiled based on questions from previous studies as well as questions adapted to the Macedonian context. At first, the questions were discussed with experts in the field and then tested on a smaller sample for general comprehension and face validity. The remaining 35 questions were provided to a larger sample of 1272 employees in SMEs in Macedonia, including the employees that are part of the sample presented in this survey. The initial data analysis involved factor analysis (PCA with Varimax rotation) as well as an internal consistency check using Cronbach Alpha. The results are presented in Table 1. As can be seen, the factor analysis produced a 6 factor solution but the last two factors did not have good internal consistency and were therefore deemed inappropriate. The rest of the factors were used for further analysis. As such, the Decision Making and Behavior dimension contains 7 questions (Q1, Q2, Q3, Q9, Q10, Q11 and Q12). The People versus Task dimension contain 4 questions $(\mathrm{Q} 15$, Q16, Q32, Q33). The Innovativeness and Risk Taking dimension contains four questions (Q27, Q29, Q34 and Q35). Finally, the Open versus Closed system dimension contains three questions (Q18, Q19 and Q21). The analysis for the present paper is based on those remaining questions. The cut-off point for deciding between high and low scores is the theoretical mean of the scale (2.5).

Table 1. Factor and analysis and Cronbach Alpha results

\begin{tabular}{|c|c|c|c|c|c|c|}
\hline \multicolumn{7}{|c|}{ Rotated Component Matrix } \\
\hline & \multicolumn{6}{|c|}{ Component } \\
\hline & $\begin{array}{c}1 \\
\text { DMB }\end{array}$ & $\begin{array}{c}2 \\
\mathrm{PT}\end{array}$ & $\begin{array}{c}3 \\
\text { IRT }\end{array}$ & $\begin{array}{c}4 \\
\mathrm{OC}\end{array}$ & 5 & 6 \\
\hline Q1 & .733 & .116 & .170 & .038 & -.078 & .005 \\
\hline Q2 & .818 & -.008 & .160 & .082 & .008 & .028 \\
\hline Q3 & .718 & .021 & .121 & .127 & -.131 & .015 \\
\hline Q9 & .752 & .029 & .103 & .197 & -.016 & -.023 \\
\hline Q10 & .697 & .080 & .140 & .285 & -.033 & -.112 \\
\hline Q11 & .728 & .091 & .155 & .224 & -.075 & -.063 \\
\hline Q12 & .748 & .122 & .187 & .184 & -.028 & -.159 \\
\hline Q18 & .265 & -.016 & .216 & .727 & .043 & -.044 \\
\hline Q19 & .393 & -.013 & .172 & .691 & .068 & .015 \\
\hline Q21 & .206 & .001 & .119 & .716 & -.102 & -.037 \\
\hline Q27 & .314 & .049 & .525 & .346 & -.099 & .083 \\
\hline Q29 & .225 & .096 & .686 & .162 & -.080 & -.007 \\
\hline Q34 & .166 & .020 & .760 & .050 & .093 & -.029 \\
\hline Q35 & .181 & .000 & .696 & .138 & -.145 & -.064 \\
\hline Q5Rec & -.194 & -.216 & -.060 & -.013 & .741 & .054 \\
\hline Q7Rec & .047 & .196 & -.012 & .070 & .809 & .058 \\
\hline Q13Rec & -.039 & .204 & .049 & -.027 & .206 & .725 \\
\hline Q14Rec & -.094 & -.019 & -.085 & -.020 & .063 & .837 \\
\hline Q15Rec & .037 & .695 & -.065 & .118 & -.076 & .145 \\
\hline Q16Rec & .071 & .750 & .090 & .105 & -.028 & -.005 \\
\hline Q32Rec & .073 & .697 & .099 & -.168 & -.006 & .019 \\
\hline Q33Rec & .077 & .731 & .004 & -.058 & -.051 & .009 \\
\hline Q22Rec & -.116 & -.262 & -.115 & -.127 & .664 & .261 \\
\hline $\begin{array}{c}\text { Cronbach } \\
\text { Alpha }\end{array}$ & .894 & .708 & .719 & .727 & .204 & .306 \\
\hline
\end{tabular}

In accordance with the methodology proposed by Vox Organizations, an employee survey was conducted in all three companies. To ensure anonymity and confidentiality, the companies will be named A, B and C in the text. The total number of participants is 52 . The age dissemination of 
the sample indicates that the majority of the employees $(38.5 \%)$ are between 20 and 30 years old. There is an equal split of participants who are between 31 and 40 (25\%), and those who are between 41 and 50 years old (25\%). The category of participants above 51 years accounts for $11.5 \%$. $51.9 \%$ of the employees hold bachelor's degree, $40.4 \%$ have only a secondary school diploma, while $7.7 \%$ have a master's degree. In terms of years of working experience in the company, $19.2 \%$ have less than 1 year of working experience in the company, $26.9 \%$ have been working for between 1 and 5 years in the company, $40.4 \%$ have between 6 and 10 years and $13.5 \%$ have more than 10 years of working experience in the studied companies. $21.2 \%$ of the overhaul employees are in managerial positions. According to the information gathered from the interviews with the organizations' management, by profession, $78 \%$ of the respondents are electrical engineers and electricians. The rest of the $22 \%$ of the employees are IT specialists and mechanical, civil and chemical engineers.

\section{Results}

To gain insight into the organizational culture in the sector, the scores for each dimension of the organizational culture were first calculated. The descriptive statistics are presented as mean and standard deviation for each company and are used to determine each company's cultural dimensions (Table 2). As can be seen, the overall results show that the employees perceive a tendency towards the companies being more democratic rather than bureaucratic. They also perceive that the companies are paying slightly more attention to the people than the tasks and are indecisive, although they are more inclined towards being less innovative and less willing to take risks. The employees also perceive that the companies are open systems.

Table 2. Descriptive statistics for each dimension

\begin{tabular}{|c|c|}
\hline Dimension & Mean \pm Std. deviation \\
\hline Decision making and behavior & $2.91 \pm 0.335$ \\
\hline People - Task & $2.6 \pm 0.31$ \\
\hline Innovativeness and risk taking & $2.47 \pm 0.279$ \\
\hline Open - Close System & $2.82 \pm 0.422$ \\
\hline
\end{tabular}

The Shapiro-Wilk test, which is an extension of the validation of the questionnaire as well as basis for the future usage of statistical tests, presented in Table 3, showed that the group's data were normally distributed. This is verified by the significance level, which for all dimensions is greater than 0.05 .
Table 3. Tests of Normality for each dimension

\begin{tabular}{|c|c|c|c|c|}
\hline \multirow{2}{*}{} & \multirow{2}{*}{ Company } & \multicolumn{3}{|c|}{ Shapiro-Wilk } \\
\cline { 2 - 5 } & & Statistic & Df & Sig. \\
\hline \multirow{3}{*}{$\begin{array}{c}\text { Decision making } \\
\text { and behavior }\end{array}$} & $\mathrm{A}$ & 0.969 & 17 & 0.802 \\
\cline { 2 - 5 } & $\mathrm{B}$ & 0.937 & 29 & 0.082 \\
\cline { 2 - 5 } & $\mathrm{C}$ & 0.923 & 6 & 0.530 \\
\hline \multirow{3}{*}{\begin{tabular}{c} 
People-Task \\
\cline { 2 - 5 }
\end{tabular}} & $\mathrm{A}$ & 0.933 & 17 & 0.240 \\
\cline { 2 - 5 } & $\mathrm{B}$ & 0.940 & 29 & 0.101 \\
\hline \multirow{3}{*}{$\begin{array}{c}\text { Innovativeness and } \\
\text { risk taking }\end{array}$} & $\mathrm{C}$ & 0.902 & 6 & 0.387 \\
\cline { 2 - 5 } & $\mathrm{B}$ & 0.937 & 17 & 0.285 \\
\hline & $\mathrm{C}$ & 0.914 & 6 & 0.463 \\
\hline \multirow{2}{*}{$\begin{array}{c}\text { Open-Close } \\
\text { System }\end{array}$} & $\mathrm{A}$ & 0.969 & 17 & 0.793 \\
\cline { 2 - 5 } & $\mathrm{B}$ & 0.943 & 29 & 0.121 \\
\cline { 2 - 5 } & $\mathrm{C}$ & 0.976 & 6 & 0.933 \\
\hline
\end{tabular}

The exploration of organizational culture in the SMEs continued by checking for differences between the companies. The groups were checked for equality of variances in order to determine the best method for the statistical analysis of the data and for the interpretation of the results of those tests. The results of the test are presented in Table 4.

Table 4. Test of Homogeneity of Variances

\begin{tabular}{|c|c|c|c|c|}
\hline & $\begin{array}{c}\text { Levene } \\
\text { Statistic }\end{array}$ & df1 & df2 & Sig. \\
\hline $\begin{array}{c}\text { Decision making and } \\
\text { behavior }\end{array}$ & 0.108 & 2 & 49 & 0.897 \\
\hline People - Task & 2.232 & 2 & 49 & 0.118 \\
\hline $\begin{array}{c}\text { Innovativeness and } \\
\text { risk taking }\end{array}$ & 0.783 & 2 & 49 & 0.463 \\
\hline Open-Close System & 6.061 & 2 & 49 & 0.004 \\
\hline
\end{tabular}

Table 5. One-way ANOVA

\begin{tabular}{|c|c|c|c|c|c|}
\hline & & $\begin{array}{l}\text { Sum of } \\
\text { Squares }\end{array}$ & Df & $\begin{array}{l}\text { Mean } \\
\text { Square }\end{array}$ & $\mathrm{F}$ \\
\hline \multirow{3}{*}{$\begin{array}{c}\text { Decision } \\
\text { making and } \\
\text { behavior }\end{array}$} & $\begin{array}{c}\text { Between } \\
\text { Groups }\end{array}$ & 4.257 & 2 & 2.128 & 0.227 \\
\hline & $\begin{array}{l}\text { Within } \\
\text { Groups }\end{array}$ & 458.416 & 49 & 9.355 & \\
\hline & Total & 462.673 & 51 & & \\
\hline \multirow{3}{*}{ People - Task } & $\begin{array}{c}\text { Between } \\
\text { Groups }\end{array}$ & 56.249 & 2 & 28.124 & 5.345 \\
\hline & $\begin{array}{l}\text { Within } \\
\text { Groups }\end{array}$ & 257.828 & 49 & 5.262 & \\
\hline & Total & 314.077 & 51 & & \\
\hline \multirow{3}{*}{$\begin{array}{l}\text { Innovativeness } \\
\text { and risk taking }\end{array}$} & $\begin{array}{c}\text { Between } \\
\text { Groups }\end{array}$ & 21.995 & 2 & 10.998 & 3.113 \\
\hline & $\begin{array}{l}\text { Within } \\
\text { Groups }\end{array}$ & 173.082 & 49 & 3.532 & \\
\hline & Total & 195.077 & 51 & & \\
\hline
\end{tabular}

The statistical significance (presented in Table 4) for all dimensions except OC was higher than 0.05 and allowed the researchers to proceed to a One-Way Anova (presented in Table 5) to interpret the results, while for the OC dimension heterogeneity of variances was detected and therefore Welch ANOVA (presented in Table 6) was used to interpret the results. 
The One-Way and Welch Anova tests showed that there was no statistical difference in the means of Decision making and behavior, Innovativeness and Risk Taking and Open versus Closed system dimensions. The exception of this is the People versus Task dimension for which the p-value is less than 0.05 .

Table 6. Welch ANOVA (Robust Tests of Equality of Means)

\begin{tabular}{|c|c|c|c|c|c|}
\hline \multicolumn{2}{|l|}{} & Statistica & df1 & df2 & Sig. \\
\hline $\begin{array}{c}\text { Open-Close } \\
\text { System }\end{array}$ & Welch & 1.562 & 2 & 20.499 & .234 \\
\hline
\end{tabular}

The values of the DMB means (Table 2 and Table 5) are around the mid-point between the possible minimum and maximum with prevalence being towards the higher score, which indicates that the companies nurture democratic values in decision making. The PT means show a balance between making sure to get the job done and the well-being of the employees, with more orientation towards human relationships in Company A (Table 2 and Table 5). The IRT means of the three companies are moderate, indicating that the companies tend to stability but at the same time they encourage an entrepreneurial spirit and original ideas in order to sustain themselves long-term. This trend is stronger in Company A than in Companies B and C (Table
2 and Table 5). The OC scores show slightly higher openness towards external systems and more transparency in the flow of information towards employees and acceptance of newcomers in Companies $\mathrm{A}$ and $\mathrm{C}$ as compared to Company B (Table 2 and Table 6).

The study further examined if there were differences in the scores of the respondents based on their demographical characteristics by running the Kruskal-Wallis $\mathrm{H}$ test. The four cultural dimensions' scores were checked against 6 demographic variables: age, gender, education, current position in the company, work experience in the current company and work experience in the current position. The values are presented as mean ranks and are summarized in Table 7. The distributions of all four dimensions' scores were not similar for any groups in each category. No statistically significant difference was found between different age groups. Females tend to think that the organizations are more democratic than males (mean ranks: $3.85>2.64$ ) and the gender scores difference is statistically significant. The "Education" and "Current position in the company" showed statistically significant differences between the demographic groups for all dimensions. "Work experience in the company" and "Work experience in the current position" showed statistically significant differences between groups for some of the dimensions.

Table 7. Kruskall-Wallis test for each cultural dimension for the 6 demographic variables (the $\mathrm{p}$ values in bold are statistically significant)

\begin{tabular}{|c|c|c|c|c|c|}
\hline \multirow{2}{*}{\multicolumn{2}{|c|}{$\begin{array}{c}\text { Demographic category } \\
\left(\chi^{2}=\text { Test statistics } ; p=\text { mean rank }\right)\end{array}$}} & \multicolumn{4}{|c|}{ Cultural dimensions } \\
\hline & & \multirow{2}{*}{$\begin{array}{c}\begin{array}{c}\text { Decision making } \\
\& \text { behavior }\end{array} \\
0.598\end{array}$} & \multirow{2}{*}{$\begin{array}{c}\text { People-Task } \\
1.036\end{array}$} & \multirow{2}{*}{$\begin{array}{c}\begin{array}{c}\text { Innovativeness \& Risk } \\
\text { taking }\end{array} \\
2.229 \\
\end{array}$} & \multirow{2}{*}{$\begin{array}{c}\text { Open vs. } \\
\text { Closed system } \\
0.224\end{array}$} \\
\hline & $\chi^{2}(3)$ & & & & \\
\hline Deg. Of freedom $=3$ & $p$ & 0.897 & 0.793 & 0.526 & 0.974 \\
\hline \multirow{2}{*}{$\begin{array}{l}\text { Gender } \\
\text { Deg. of freedom }=1\end{array}$} & $\chi^{2}(1)$ & 5.220 & 2.226 & 1.440 & 0.224 \\
\hline & $p$ & 0.022 & 0.136 & 0.230 & 0.166 \\
\hline \multirow{2}{*}{$\begin{array}{c}\text { Education } \\
\text { Deg. of freedom }=2\end{array}$} & $\chi^{2}(2)$ & 12.5 & 25.159 & 21.615 & 16.476 \\
\hline & $p$ & $<0.05$ & $<0.05$ & $<0.05$ & $<0.05$ \\
\hline \multirow{2}{*}{$\begin{array}{l}\text { Current position in the } \\
\text { company } \\
\text { Deg. of freedom }=1\end{array}$} & $\chi^{2}(1)$ & 19.571 & 14.073 & 13.213 & 16.898 \\
\hline & $p$ & $<0.05$ & $<0.05$ & $<0.05$ & $<0.05$ \\
\hline \multirow{2}{*}{$\begin{array}{l}\text { Years of work with the } \\
\text { company } \\
\text { Deg. of freedom }=3\end{array}$} & $\chi^{2}(3)$ & 8.343 & 7.362 & 5.553 & 11.83 \\
\hline & $p$ & 0.039 & 0.061 & 0.136 & 0.008 \\
\hline \multirow{2}{*}{$\begin{array}{l}\text { Years of work in the } \\
\text { current position } \\
\text { Deg. of freedom =3 }\end{array}$} & $\chi^{2}(3)$ & 7.615 & 4.823 & 6.577 & 8.38 \\
\hline & $p$ & 0.055 & 0.185 & 0.087 & 0.039 \\
\hline
\end{tabular}

Table 8. DMB, PT, IRT, OC - level of education average rank distribution and statistical significance

\begin{tabular}{|c|c|c|c|c|c|c|c|c|c|}
\hline \multirow{2}{*}{$\begin{array}{c}\text { Cultural } \\
\text { dimension }\end{array}$} & \multicolumn{2}{|c|}{$\begin{array}{c}\text { Sample pair } \\
\text { Secondary Sch. - BSc. }\end{array}$} & \multirow{2}{*}{$\begin{array}{c}\text { Adj. } \\
\text { Sig. } \\
(<0.05)\end{array}$} & \multicolumn{2}{|c|}{$\begin{array}{c}\text { Sample pair } \\
\text { Secondary Sch. - MSc. }\end{array}$} & \multirow{2}{*}{$\begin{array}{c}\text { Adj. } \\
\text { Sig. } \\
(<0.05)\end{array}$} & \multicolumn{2}{|c|}{$\begin{array}{l}\text { Sample pair } \\
\text { BSc. - MSc. }\end{array}$} & \multirow{2}{*}{$\begin{array}{c}\text { Adj. } \\
\text { Sig. } \\
(>0.05)\end{array}$} \\
\hline & $\begin{array}{l}\text { Secondary } \\
\text { Mean rank }\end{array}$ & $\begin{array}{c}\text { BSc. } \\
\text { Mean rank }\end{array}$ & & $\begin{array}{l}\text { Secondary } \\
\text { Mean rank }\end{array}$ & $\begin{array}{c}\text { MSc. } \\
\text { Mean rank }\end{array}$ & & $\begin{array}{c}\text { BSc. } \\
\text { Mean rank }\end{array}$ & $\begin{array}{c}\text { MSc. } \\
\text { Mean rank }\end{array}$ & \\
\hline DMB & 18 & 31.19 & 0.007 & 18 & 39.50 & 0.025 & 31.19 & 39.50 & 0.896 \\
\hline PT & 14.02 & 33.98 & $<0$ & 14.02 & 41.50 & 0.002 & 33.98 & 41.50 & 1 \\
\hline IRT & 14.83 & 34 & $<0$ & 14.83 & 37.12 & 0.019 & 34 & 37.12 & 1 \\
\hline OC & 16.83 & 31.61 & 0.002 & 16.83 & 42.75 & 0.005 & 31.61 & 42.75 & 0.5 \\
\hline
\end{tabular}


To uncover which demographic groups are different in terms of answers on different dimensions where statistically significant differences were uncovered, pair wise comparisons of the mean ranks were conducted in order to determine which groups were truly different from one another. The results were broken down per category and the results pointing out the characteristic differences detected are outlined below.

For "Current position in the company," multiple comparisons were not performed as there are less than three test fields. The findings point that Managers score statistically significantly higher than non-managers on all four dimensions. The cross tabulations show that on the DMB dimension, almost all the respondents from the managerial group scored above 3.22, while all the respondents from the non-managerial group scored below 3.22. This means that the managers are more inclined to think that the company's organizational culture is democratic in comparison to non-managers. Similarly, on the P-T dimension, the score of 2.63 appears to be a breaking point - all the managers scored 2.63 and above, while the majority of non-managers scored 2.63 and below. This means that although all employees tend to view the culture as more people- than task- oriented, this is more so the case with managers rather than those in non-managerial positions. The IRT scores in the managerial group are 2.43 and higher, while most of the respondents from the non-managerial group scored 2.43 or less. This means that the managers tend to perceive the culture as more innovative and risk taking than non-managers. The O-C scores show that 12 out of 41 respondents belonging to the non-managerial group scored above 2.9 and the majority of them scored below 2.9. The majority of the respondents in managerial positions scored 3 or higher on the O-C dimension. This means that although the employees in general think that the culture is more open than closed, this is more the case with managers than with the non-managers.

The results for the level of education are given in Table 8 . Respondents with only secondary education score lower than the BSc and MSc groups on all four dimensions and these differences are statistically significant. This means that those with lower education perceive the cultures as less democratic, less people oriented, less innovative and less open than those with higher levels of education.

The results for "Work experience in the company" are given in Table 9. The results show that respondents with more than 10 years within the company score statistically significantly differently (higher) on the DMB and OC dimensions compared to the respondents who have been within the company for 6 to 10 years. This means than the more experienced employees perceive the organizational culture to be more democratic, more people oriented, more innovative and more open than those with less experience in the company.
Table 9. DMB and O-C - "Work experience in the company" average rank distribution and statistical significance

\begin{tabular}{|c|c|c|c|}
\hline & & DBM & $\mathrm{OC}$ \\
\hline \multirow{3}{*}{$\begin{array}{l}\text { Sample pair } \\
\mathbf{6 - 1 0 / 1 - 5}\end{array}$} & 6-10 Mean rank & 21.29 & 19.79 \\
\hline & 1-5 Mean rank & 25.82 & 27.5 \\
\hline & Adj.Sig. $>0.05$ & 1 & 0.822 \\
\hline \multirow{3}{*}{$\begin{array}{l}\text { Sample pair } \\
\mathbf{6 - 1 0} /<1\end{array}$} & 6-10 Mean rank & 21.29 & 19.79 \\
\hline & $<1$ Mean rank & 29.2 & 28.4 \\
\hline & Adj.Sig. $>0.05$ & 1 & 0.815 \\
\hline \multirow{3}{*}{$\begin{array}{l}\text { Sample pair } \\
\mathbf{6 - 1 0} />\mathbf{1 0}\end{array}$} & 6-10 Mean rank & 21.29 & 19.79 \\
\hline & $>10$ Mean rank & 39.64 & 41.93 \\
\hline & Adj.Sig. $>0.05$ & 0.029 & 0.004 \\
\hline \multirow{3}{*}{$\begin{array}{l}\text { Sample pair } \\
\mathbf{1 - 5} /<\mathbf{1}\end{array}$} & 1-5 Mean rank & 25.82 & 27.5 \\
\hline & $<1$ Mean rank & 29.2 & 28.4 \\
\hline & Adj.Sig. $>0.05$ & 1 & 1 \\
\hline \multirow{3}{*}{$\begin{array}{l}\text { Sample pair } \\
\mathbf{1 - 5} />\mathbf{1 0}\end{array}$} & 1-5 Mean rank & 25.82 & 27.5 \\
\hline & $>10$ Mean rank & 39.64 & 41.93 \\
\hline & Adj.Sig. $>0.05$ & 0.273 & 0.229 \\
\hline \multirow{3}{*}{$\begin{array}{l}\text { Sample pair } \\
<\mathbf{1} />\mathbf{1 0}\end{array}$} & $<1$ Mean rank & 29.2 & 28.4 \\
\hline & $>10$ Mean rank & 39.64 & 41.93 \\
\hline & Adj.Sig. $>0.05$ & 0.935 & 0.407 \\
\hline
\end{tabular}

The results for "Work experience in the current position" are presented in Table 10. The data signify that OC dimension scores are distributed differently among the respondent groups with different numbers of years in the same position, but it cannot be concluded where the differences lie.

Table 10. OC - "Work experience in the current position" average rank distribution and statistical significance

\begin{tabular}{|c|c|c|}
\hline \multirow{3}{*}{$\begin{array}{l}\text { Sample pair } \\
\mathbf{1 - 5} /<1\end{array}$} & 6-10 Mean rank & 23.18 \\
\hline & 1-5 Mean rank & 23.72 \\
\hline & Adj.Sig. $>0.05$ & 1 \\
\hline \multirow{3}{*}{$\begin{array}{l}\text { Sample pair } \\
\mathbf{1 - 5} / \mathbf{6 - 1 0}\end{array}$} & 6-10 Mean rank & 23.18 \\
\hline & $<1$ Mean rank & 34.7 \\
\hline & Adj.Sig. $>0.05$ & 0.267 \\
\hline \multirow{3}{*}{$\begin{array}{l}\text { Sample pair } \\
\mathbf{1 - 5} />10\end{array}$} & 6-10 Mean rank & 23.18 \\
\hline & $>10$ Mean rank & 47 \\
\hline & Adj.Sig. $>0.05$ & 0.192 \\
\hline \multirow{3}{*}{$\begin{array}{l}\text { Sample pair } \\
<\mathbf{1 / 6}-10\end{array}$} & 1-5 Mean rank & 23.72 \\
\hline & $<1$ Mean rank & 34.7 \\
\hline & Adj.Sig. $>0.05$ & 0.385 \\
\hline \multirow{3}{*}{$\begin{array}{l}\text { Sample pair } \\
<\mathbf{1} />\mathbf{1 0}\end{array}$} & 1-5 Mean rank & 23.72 \\
\hline & $>10$ Mean rank & 47 \\
\hline & Adj.Sig. $>0.05$ & 0.227 \\
\hline \multirow{3}{*}{$\begin{array}{l}\text { Sample pair } \\
\mathbf{6 - 1 0} />\mathbf{1 0}\end{array}$} & $<1$ Mean rank & 34.7 \\
\hline & $>10$ Mean rank & 47 \\
\hline & Adj.Sig. $>0.05$ & 1 \\
\hline
\end{tabular}




\section{Conclusions}

Organizational culture is closely linked to various parameters of organizational success and therefore is an important aspect of organizational functioning. As such, it has been a focus of research in a number of studies and there exist numerous instruments for its measurement. However, it has been sparsely researched in South-Eastern Europe and it has been rarely studied in the SME sector. Therefore, this paper aimed at showing the applicability of an instrument developed to measure the organizational culture in SMEs in South Eastern Europe. The study was implemented in three SMEs in the Republic of Macedonia.

The results reveal the value of studying company organizational culture and show the value of understanding the different dimensions proposed and measured by the Vox Organizations instrument. As the study was conducted on a small sample, a conclusion about the predominant organizational culture in the electrical engineering service sector in Macedonian SMEs cannot be drawn. However, the results of the research can, to the studied companies, serve as base for building a strategic framework for their long-term sustainability. The research of the study and the differences in the scores of the respondents from different educational level groups clearly indicate that education plays significant role in how respondents understand and perceive organizational culture. Those with higher levels of education perceive the organizational culture in a more positive light than those with lower level of education. Therefore, one of the recommendations for achieving high performance for all three companies is to move beyond professional education and invest in the employees' familiarization with contemporary market-oriented practices via various forms of training. To detach from risk aversion which, despite being not terribly high, is still present in the surveyed electrical engineering companies, focus should be put on building confidence in organizations' leaders, raising the competence of the employees, nurturing interactions with the external environment, expertise and internal knowledge-sharing among the members of the organization. The results also point out that the managers and more experienced workers have more positive notions of the organizational culture in comparison to non-managers and less experienced workers. This means that the companies might need to focus their attention on engaging with the employees in non-managerial positions and the less experienced staff in terms of clearly sharing organizational values, practices and providing more employee engagement opportunities, so that all employees' views are aligned.

Although the paper provided measurement of the organizational cultures of the chosen electrical engineering companies based on the organizational alignment model with the use of VOX Organizations, it also provides solid ground for other studies. One such study could be "diagnosing" the predominant organizational culture in terms of tendencies of the organizational functioning of SMEs from the electrical engineering services sector in Macedonia. In order to listen to "the voice of the organizations from the electrical engineering service sector" and draw conclusions on the aforementioned question, a research should be conducted on a larger representative sample. To avoid unequal distribution, the sample and its subsets (companies) should be chosen carefully in terms of size in order to avoid the situation occurring in this research where a conclusion on how demographics influence each of the company is not applicable because of the size of each subset deriving from the VOX Organizations approach. To completely validate the Vox Organizations for use in the SMEs sector, a representative random sample from organizations in different sectors should be used in future studies.

\section{Appendix 1. The Questions in the Instrument}

Q1. The organization has clear "rules of the game".

Q2. There is an atmosphere of trust in this organization.

Q3. When changes are made, the decisions are openly and on time communicated to the relevant parties.

Q4. Leaders and managers consult with subordinates in the decision making process.

Q5.The organization has written policies and procedures***.

Q6. Achieving the results is more important than following the procedures.

Q7. The decisions are centralized at the top***

Q8. The employees are trusted to act according to organizationally accepted norms and standards in situations not governed by organizational rules and procedures

Q9. There is shared understanding of the appropriate behavior in the organization

Q10. The organization provides employees with opportunity for professional development and growth

Q11. The organization takes care about the social atmosphere and employee relations

Q12. The organization respects its employees and treats them in a consistent and fair manner

Q13. The organization is only interested in the work people do***

Q14. The organization considers employee's private lives as their own business $* * *$

Q15. The organization pays little attention to physical work environment***

Q16. The management is stingy with small things***

Q17. Employees receive timely feedback about their performance (formal or informal)

Q18. The organization encourages experimenting and trying new things

Q19. Employees are encouraged to develop new and original ideas and/or products 
Q20. Employees are encouraged "not to rock the boat"****

Q21. The organization considers innovation and appropriate level of risk taking as a way to build long term sustainability

Q22. The organization cherishes stability as a prerequisite for the long term sustainability***

Q23. The organization does not take risks, it uses tried and tested approach***

Q24. Employees and the organization try to be pioneers Q25. The organization encourages intra-departmental collaboration

Q26. The organization encourages inter-department collaboration

Q27. The organization encourages collaboration with customers and/or suppliers

Q28. The performance management system supports group work

Q29. The organization strives to expand in markets

Q30. The organization invests in learning new things

Q31. The organization does not have special ties with local community***

Q32. The organization and people are closed and secretive***

Q33. In this organization new employees need more than a year to feel at home***

Q34. The organization puts emphasis on meeting customer needs

Q35. The organization nurtures positive collaboration with other companies, even if they are competitors

$* * *$ reverse coded

\section{REFERENCES}

[1] E. Schein, Organizational Culture and Leadership, Jossey-Bass, San Francisco, 2010.

[2] M. Alvesson, Understanding Organizational Culture,, SAGE Publications, London, 2002.

[3] D.R. Denison, A.K. Mishra, Organizational Culture and Organizational Effectiveness, Academy of Management Proceedings, 1989, Vol. 1, 168-172.

[4] J.P. Kotter, J.L. Heskett, Corporate culture and performance, Free Press, New York, 1992.

[5] D. Dauber, G. Fink, M. Yolles, Configuration Model of Organizational Culture, Sage Open, 2012, 1-16.

[6] R. Gray, Organizational culture and psychological contract, Kumpania Consulting, 1998.

[7] M.T. Khan, N. A. Khan, A. Sheraz, A. Mahfooz, Connotation of Organizational Culture - Models and Categories. Universal Journal of Management and Social Sciences, 2012, Vol. 2, No.9, 39-49.

[8] G. Hofstede, Identifying organizational subcultures: an empirical approach, Journal of Management Studies, 1998,
Vol.35, No.1, 1-12.

[9] G. Hofstede, Attitudes, values and organizational culture: Disentangling the concepts. Organization Studies, 1998, Vol. 19, No. 3, 477-492.

[10] G. Hofstede, G.J. Hofstede, M. Minkov, Cultures and Organizations: Software of the Mind, McGraw-Hill, New York, 2010.

[11] C. A. O'Reilly, J. Chatman, D.F. Caldwell, People and organizational culture: A profile comparison approach to assessing person-organization fit, Academy of Management Journal, 1991, Vol. 34, 487-516.

[12] S. K. Cameron, E. R. Quinn, Diagnosing and changing organizational culture, Jossey Bass, San Francisco, 2006.

[13] R. J. House, P. J.,Hanges, J. Mansour, P. W. Dorfman, V.Gupta, Culture, Leadership and Organizations: The GLOBE Study of 62 Societies, Sage Publications, Thousand Oaks, 2004.

[14] T. Jung, J.T. Scott, H.O.T. Davies, P. Bower, D. Whalley R. McNally, R. Mannion, Instruments for the Exploration of Organisational Culture: A review of the literature, Public Administration Review, 2009, Vol. 69, No.6, 1087-1096.

[15] Y.S. Choi, M. Seo, D. Scott, J.J. Martin, Validation of the Organizational Culture Assessment Instrument: An application of the Korean version, Journal of Sport Management, 2010, Vol. 24, No.2, 169-189.

[16] A. Dastmalchian, S. Lee, I. Ng, The interplay between organizational and national cultures: A comparison of organizational practices in Canada and South Korea using the Competing Values Framework, International Journal of Human Resource Management, 2000, Vol. 11, No. 2, 388-412.

[17] P. Anderson, Complexity theory and organization science, Organization Science, 1999, Vol. 10, No.3, 216-232.

[18] Z. Zhichang, Complexity science, system thinking and pragmatic sensibility, System Research and Behavioral Science, 2007, Vol. 24, No. 4, 445-464.

[19] M.I. Mateev, Y. Anastasov, On the Growth of Micro, Small and Medium-Sized Firms in Central and Eastern Europe: A Dynamic Panel Analysis, Banking \& Finance Review, 2011, Vol. 3, No. 2, 81-103.

[20] A. Psychogios, S. Garev, Understanding Complexity Leadership Behavior in SMEs: Lessons from a Turbulent Business Environment Emergence, Emergence: Complexity and Organization, 2012, Vol. 14, No. 3, 1-22.

[21] M. Stoica, L., Florea, E. Lukacs, Small Business Responsiveness in a Developing Economy: Does Organizational Culture Matter?, Annals of "Dunarea de Jos" University of Galati, 2012 Vol. 3, 1-14.

[22] N. Borak, Ekonomski vidiki delovanja in razpada Jugoslavije, Znanstveno in publicistično središče, Ljubljana.2002.

[23] State Statistical Office of the Republic of Macedonia, Labour Force Survey, 2017, Online available at http://www.stat.gov.mk/Publikacii/2.4.18.03.pdf.

[24] M. Dimitrova, J. Vadnjal, I. Petrovska, M. Bojadziev, 
Should I become an entrepreneur or an employee: dilemmas of students in Macedonia and Slovenia, Acta Oeconomica Universitatis Selye, 2014, 35-45.

[25] A. Tomovska Misoska, M. Dimitrova, J. Mrsik, Drivers of entrepreneurial intentions among business students in Macedonia, Economic Research-Ekonomska Istrazivanja, 2016, Vol. 29, No. 1, 1062-1074.

[26] M.M. Camina, Research Note: Cultural gaps in cross-national cooperation: the legacy of Empires in Macedonia, Organization Studies, 2000, Vol. 21, 119-132.

[27] M. Bojadziev, V. Krliu, Organizational culture as a driving force in modern organizations, 2nd Annual International Conference on European Integration of University American College Skopje, 116-127, 2007.

[28] M. Magdinceva-Sopova, Menadzment na organizaciskata kultura (Management of organizational culture), Sofija, Bogdanci, 2012.

[29] A. Tomovska-Misoska, M. Bojadziev, M. Stefanovska, Z. Nikolovska, VOX Organizationis - theoretical basis and methodological considerations in the development of an instrument for organizational culture, 2011, Online available at: http://mpra.ub.uni-muenchen.de/42571/.

[30] A. Limani, A. Tomovska-Misoska, M. Bojadjiev, Organizational alignment as a model of sustainable development in the public sector in the Republic of Macedonia, Journal of Sustainable Development, 2015, Vol. $5,51-68$.

[31] M. Bojadziev, A. Tomovska Misoska, A. Pesev, M. Stefanoska Petkovska, Organizational alignment in ICT company in the Republic of Macedonia, Business and Economic Research, 2016, Vol. 6, 424-439.

[32] R.A. Cooke, J.L. Szumal, Using the Organizational Culture Inventory to understand the operating of cultures on organizations in N. M. Ashkanasy, C.P.M. Wilderom, M.F. Peterson (eds), Handbook of organizational culture and climate, Sage Publications, Thousand Oaks, 2000.

[33] G. Hofstede, B. Neuijen, D. D. Ohayv, G.Sanders, Measuring organizational cultures: A qualitative and quantitative study across twenty cases, Administrative Science Quarterly, 1990, Vol. 35, No.2, 286-318. 